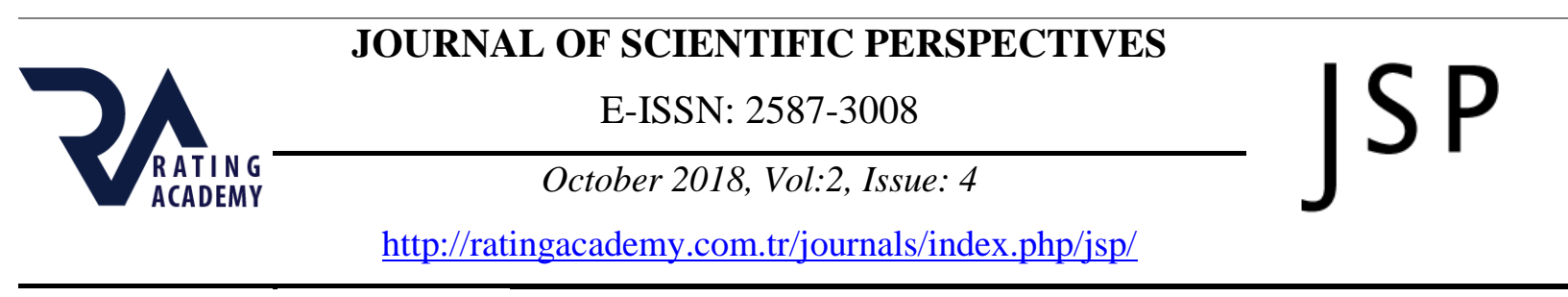

\title{
ALGAE AND DIETARY DIETS
}

\author{
Assist. Prof.Dr. Latife Ceyda IRKIN \\ Canakkale Onsekiz Mart University, School of Applied Sciences, \\ Fisheries Technology, Canakkale, Turkey \\ E-mail: latifeirkin@gmail.com
}

Assoc. Prof. Dr. Özlem TONGUÇ YAYINTAŞ

Canakkale Onsekiz Mart University, School of Applied Sciences, Fisheries Technology, Canakkale, Turkey,

E-mail: ozlemyayintas@hotmail.com

\begin{tabular}{|c|c|}
\hline ARTICLE INFO & ABSTRACT \\
\hline $\begin{array}{l}\text { Article History: } \\
\text { Received: } 5 \text { October } 2018 \\
\text { Accepted: } 29 \text { October } 2018\end{array}$ & \multirow{3}{*}{$\begin{array}{l}\text { Algae involve several species of multicellular and macroscopic marine algae } \\
\text { found in the coastal region between high to low tide in the sub-tidal region up to } \\
\text { a depth where 0.01 \% photosynthetic light is available. Based on their } \\
\text { pigmentation, seaweeds were classified in to Chlorophyta (green algae), } \\
\text { Phaeophyta (Brown algae) and Rhodophyta (Red algae). Algae are not classified } \\
\text { as true plants. They lack an organized vascular system for absorbing nutrients. } \\
\text { The root called the holdfast, the stem is the stripe and the leaf of the seaweed is } \\
\text { the blade or frond. Like flowering plants, they are able to use chlorophyll to } \\
\text { conduct the process of photosynthesis and create their own food for growth. } \\
\text { In marine ecosystems, macroalgae communities provide nutrition, reproduction, } \\
\text { and an accommodating environment for other living organisms. Algae play a vital } \\
\text { role in various aspects compared to other aquatic resources. Because of these } \\
\text { properties, macroalgae are some of the most important organisms maintaining the } \\
\text { ecosystem's stability. They are also excellent source of bioactive compounds such } \\
\text { as carotenoids, dietary fibers, proteins, essential fatty acids, vitamins, minerals } \\
\text { and important sources of medicines and fertilizers. }\end{array}$} \\
\hline $\begin{array}{l}\text { Keywords: Algae, dietary } \\
\text { diet, nutritional, health. }\end{array}$ & \\
\hline $\begin{array}{l}\text { DOI: } \\
\text { 10.26900/jsp.2018445373 }\end{array}$ & \\
\hline
\end{tabular}

\section{INTRODUCTION}

Algae is one of the primitive life forms on Earth. They are simple water plants without roots, stems or leaves. There are primitive replication methods. The ecological role of algae is to provide oxygen as well as providing a basic step for the food chain.

Algae come in different sizes, shapes, growth forms and colors. They can be single and multicellular in salt and fresh water. They are named according to their color; Blue-green, green, red and brown algae. The colors are the result of various chloroplast pigments, including chlorophylls, carotenoids and phycobiliproteins. Algae contain chlorophyll to catch the sunlight needed to pass through the phytosynthesis.

\footnotetext{
* Bu makale, 27-29 Haziran 2018 tarihlerinde düzenlenen III. Doğunun Batısı Batının Doğusu Konferansı'nda sunulmuş aynı isimli bildirinin gözden geçirilmiş halidir.
} 
Algae has been an important source of fertilizer, food and medicine since ancient times. The earliest record of using algae dates back to 2700 BC by Emperor Shen Nung (Kasimala et al., 2015). Human consumption of algae extends to the Aztec civilization in the 14th century. This type of Spirulina and Chlorella, commonly are used as a superfood supplements. The benefits of algae can play a role in prevention and treatment of diseases by various mechanisms, due to the high concentrations of minerals, vitamins, proteins and antioxidants.

People consume algae as healthy food that facilitates the elimination of heavy metals, radioactive elements, dioxins and PCBs. Algae promotes a healthy immune system, prevents thyroid disease, obesity, cancer metastases, cardiovascular diseases, diabetes, nervous system disorders, osteoporosis. Also they reduce chronic inflammation, inhibit viruses (including herpes and papilloma virus), and help regulate menstrual period.

Algae are divided into two major groups as prokaryotic (microalgae) and eukaryotic (macroalgae). Microalgae (blue-green algae, Cyanophyta) are unicellular planktonic algae, Macroalgae are according to their whips or pigmentations; Brown algae (Phaeophyta), Red algae (Rhodophyta), Green algae (Chlorophyta), Diatoms (Chrysophyta) and Flagelleta.

\subsection{Brown Algae (Phaeophyta)}

Phaeophyta is a protista branch, which constitutes a large part of multi-cell algae. They have chlorophyll a, c and fucoxanthine pigment. Unlike plants, brown algae store photosynthetic products not as starch, but as mannitol (manic acid alcohol), laminarin (a polysaccharide), algin (as a substance) and oil. On rocky beaches, they often live in cold and temperate waters. The number of brown algae living in tropical regions is small. In their life cycle, progeny is seen, followed by sexual and asexual reproduction. Large marine algae have distinct cell differentiation but do not carry any form of leaf, stem or body. The simplest species are in the form of branched yarns, whereas in the larger species the tallus have developed in the form of trunk and foliage and can develop in a very large size. About 1,500 species are known. They provide animals shelter for their food and eggs. They are also used in the food industry because they are rich in nutritional value.

\subsection{Red Algae (Rhodophyta)}

Red algae is the most advanced class of algae. They are usually filaments or leaf-shaped macro algae. This group are characterized by the red pigments. There are no differentiations in the form of leaves, roots and trunk. Algae body is wrapped with gelatinous substance. One of the most important features of red algae is that no cells, including sperm cells, carry whips.

Leaf-shaped tallus are found. By photosynthesis, they store carbohydrates in the form of fluoridean, a special starch. They may also develop in low intensity light. Unlike other algae, they can live in deeper regions. In some species, calcium carbonate is stored in cell walls. The reefs of these species, by cutting the waves, provide shelter for living creatures. Polymerstructured polymer gel, called "agar agar", is obtained from pectin-structured cell walls of them. There are also types used in the food and pharmaceutical industry.

\subsection{Green algae (Chlorophyta)}

The single-cell or multicell colony forming species are covering the sphere of plants. They contain chlorophyll a, b and various carotenoids (carotene, lutein, xanthophylls, pyrenoids). Chlorophyll is in green, making them look green. The cell wall consists of cellulosecontaining polysaccharides in some forms. Sometimes they create "tallus" by showing partial variations. Multicellular cells do not have complex cell differentiation. The photosynthesis product stores carbohydrates in the form of starches and oils. More than 9,000 species are known. $90 \%$ of them are fresh water and $10 \%$ are in seas. They are widespread at the beginning 
of spring, late summer and autumn season. They participate in lichen formation. As a result of the studies conducted, it is accepted that they are the ancestors of terrestrial plants.

\subsection{Microalgae Blue-green algae (Cyanophyta)}

Blue green algae, considered to be the first photosynthetic organisms of the earth and which have been around 3.5 billion years in the world, are the only prokaryotic group among the algae groups. Blue green algae, like other algae in aquatic life, take the first place in the food chain. These are living things that do not have a specific cell nucleus with a simple cell structure. Blue - green algae are as small as bacteria. They either live as individual cells or colonies. Due to their versatile metabolism, they can easily adapt to different environmental conditions. They are found in damp soils and in waters. There are no organelles and nuclei. They can do photosynthesis. When they overgrow, they reduce the oxygen of the water, cause turbidity and prevent the light from going into deep water. This can damage deep-water creatures. In addition to their biological role in ecosystem; various active ingredients, proteins, pigments, fatty acids, vitamins, antibiotics, polysaccharides and many other metabolites naturally accumulate. For this reason, this group provides economic contribution in many areas such as food, cosmetics and energy.

\section{NUTRITIONAL VALUES OF ALGAE}

160 species of marine algae (algae) commonly used in Far East countries, especially in China, Korea and Japan and consumed as food. Algae are very rich in carbohydrates, proteins, lipids, fatty acids, glycerol, natural pigments (beta-carotene, astaxanthin, xanthophylls, fikobilin) and amino acids (Durmaz et al., 2002). and bioactive substances (Chandini et al., 2008) with antibacterial, antifungal and antiviral properties such as polyphenols.

Algae are rich in protein, fat and water-soluble fiber, as well as minerals such as iron, magnesium, potassium and zinc, which are important in nutrition. Significantly they contain vitamins $\mathrm{K}$ and $\mathrm{E}$, ribofilavine, thiamine, niacin. Algae's antioxidants, vitamins and pigments as well as are a rich source of polyunsaturated fatty acids (Gökpınar et al., 2001).

\subsection{Vegetarian Omega-3 and DHA Source: Algae Oil}

Algae oil, although not very appetizing, is actually a healthy source oil with an excellent fatty acid profile. It has more monounsaturated fatty acids than olive oil (13 grams per tablespoon compared to 9.9 grams for olive oil) and contains only $4 \%$ saturated fat compared to olive (14\%), canola (7\%) and coconut $7(87 \%)$.

Algae oil contains high amounts of DHA (docosahexaenoic acid), one of the two omega3 fatty acids we need for long-term physical and mental health.

Studies have shown that supplementation with DHA from algae oil reduces the level of triglycerides in people for heart health and is able to balance HDL and LDL cholesterol levels.

Although higher LDL was not preferred. Small and dense LDL particles predict higher risk of heart disease, while larger particles may be protective (Kasimala et al., 2015).

\subsection{Benefits of Algae Oil to Our Health}

Algae oil provides a healthy pregnancy. Omega fatty acid DHA is required for brain development during pregnancy.

Algae oil promotes eye health and prevents age-related macular degeneration (yellow spot disease). The retina has a high level of DHA, and the role of DHA is biophysical interactions on the cell membrane. 
Algae oil has protective and supportive effects on cardiovascular health. It helps to regulate heart rate, reduces blood pressure and blood clot formation, prevents inflammation. This reduces the risk of heart attack and stroke. There are also positive effects on triglycerides and LDL cholesterol.

Algae oil has the ability to support brain power and memory. Omega-3 is the key to brain development and functions. This is another reason why algae oil is important for health. $60 \%$ of the brain is composed of fat and is supported to work with high levels of DHA. DHA helps the brain's communication cells and fights aging.

Algae oil has anti-inflammatory effect. Recent studies have shown that Omega-3 fatty acids can help to minimize symptoms of osteoarthritis and pain.

Studies show that one or two grams of algae oil supplementation per day can significantly increase levels of DHA and EPA in the blood. This dose can also help to reduce triglycerides, blood pressure and heart rate, increase HDL, control inflammation (Kasimala and Kasimala, 1983).

\section{CONSUMED ALGAE AS FOOD}

While 800 thousand tons of 28 million tons of seaweed produced in 43 countries are collected from nature, $94 \%$ is obtained through culture culture.

Among the edible algae, Porphyra spp. is one of the most famous species in Japan. Brown algae in, Laminaria sp. and Underis sp. are also used as other nutrients.

The nori used in sushi coating has been an important food in Japan for at least 1300 years. Nori rice sandwiches, boiled rice or noodles are used in flavoring and in different soups.

\subsection{Foods Prepared with Algae}

Nori (Purple Laver): It is an edible seaweed of Porphyra in the red algae branch. Most of $P$. yezoensis and $P$. tenera species are used. The product is made on the basis of the cutting and spreading process, which resembles paper manufacturing. Nori is often used as a winding material for sushi and onigiri. It is lightly fried immediately before use. Separately, when eaten alone, soy sauce is fried together with various spices. Similarly, there is also a food called Aonori prepared from green algae Monostroma and Enteromorpha.

Nori is rich in vitamin B complex, including vitamins B6 and B12. About one third of Nori is protein and one third is fiber. It contains high levels of iodine, carotene, vitamins A, C and calcium and iron. In Japan, 350,000 tons of production creates a market of over one billion dollars annually (https://www.livestrong.com/article/427504-list-of-foods-that-contain-algae/)

Ulva lactuca / Sea Lettuce: Ulva lactuca or Sea-Lettuce is a bright green leaf algae that is harvested in nutrient-rich waters for its delicious taste. The leaves can be flat, slender, round or oval. It can be consumed freshly as well as being mixed with pasta varieties, soups, salads, sauces and fish. When it is dried, it has been added to many recipes such as spices and flavor enhancers. It is high in protein and has nine basic amino acids. In addition, magnesium, potassium, calcium and essential vitamins (A, B, C and B12) are rich. It is rich in pigments with strong antioxidants (especially beta carotene and lutein). Beta carotene is an important antioxidant for our eye health. Lutein is an indispensable substance to repair the damage caused by UV rays of the skin. Sea lettuce contains $28 \%$ protein consisting of 9 essential amino acids, including Lysine, which is lacking in most vegetarian diets.

Wakame (Undaria pinnatifida): Wakame is an edible seaweed or kelp commonly used in Japanese, Korean and Chinese cuisines. It has a rare brown or dark green color. It contains fucoxanthine, a unique compound with rare medical and nutritional quality. 
Wakame is a low-calorie low-fat food that contains fucoxanthine, a carotenoid with antiinflammatory and anti-cancer effects. It is a rich source of carbohydrate and protein. The major component is water with some fiber and sugar. Most of these benefits come from the source of vitamins and minerals found in sensitive green leaves. Wakame is a good source of magnesium, calcium, iodine, iron, vitamins (A, C, E, K, D and B2) and folate. Antioxidants such as omega3 fatty acids and lignans are also supported. In Japan, wakame is often used in soups and salads. It has a sweet taste and a bright appearance. This delicious seaweed continues to gain popularity especially in France and other countries of the World

(https://www.livestrong.com/article/458681-algae-as-a-food-source-for-humans/).

Sea Spaghetti (Sea Spaghetti): Sea spaghetti seaweed (Himanthalia elongata) is one of the most easily recognized of all brown seaweeds. It spreads abundantly along the rocky, windy shores of the Atlantic Ocean. In autumn it develops from the disc (thallus) attached to rocks and coastline to long leaves. It grows very fast, the structure of thallus can be two to three meters long. It is usually dried or sold as pickles. In Northern Spain, the famous Spanish tortilla is used instead of green beans. Like all sea vegetables, it contains high levels of calcium, magnesium and potassium, rich in protein, fiber, vitamins and minerals. It can be eaten on its own or mixed with spaghetti. It can be cooked and added to soup.

\subsection{Benefits of Blue-Green Algae Tablets}

Blue-green algae are a living group of about 1,500 species known as rich protein sources. These plants contain carotenoids, vitamins, minerals and essential fatty acids. It has been harvested in Mexico and the Sahara Desert for a long time due to its medicinal properties.

Blue-green algae strengthens the immune system, cholesterol balancing, reduce viral infection and inhibite the effects of cancer. Blue-green algae contain antioxidants, including zeaxanthin, which can help strengthen the retina and prevent macular degeneration, which severely disrupts or destroys vision. Spirulina can also help to prevent the development of kidney stones caused by chemicals called oxalate (https://www.webmd.com/vitaminssupplements).

Both Chlorella and Spirulina have positive effects in lowering serum lipid levels. Also Chlorella and Spirulina have been studied for benefits of diabetic patients. According to a investigation in 2009 diabetic rats fed with Chlorella proved to have lower fasting glucose levels than non-fed rats.

Although Spirulina represents only a few species of most blue-green algae species, it is the most commonly used name for identifying edible blue-green algal groups. Widely used as 500 or $750 \mathrm{mg}$ tablets. The daily dose of blue-green algae is 2000-3000 $\mathrm{mg}$ (http://www.businessinsider.com/algae-is-the-superfood-of-the-future-2014-6).

\section{CONCLUSION}

What is the most important live species in the world? When this question is asked, most of us give the answer uz human "without thinking. It is very natural that we give this answer as a member of the human species.

Algae, which continue their lives by photosynthesis, are also the reason why other living things can do photosynthesis according to the endosymbiosis theory. These species, which reproduce in oceans and stagnant waters, provide oxygen to the atmosphere by photosynthesis during the day; at night they simply break down the nutrients they produce using oxygen, which is far less than they produce. 
Algae, which we describe in the oxygen cycle and in ecological relations, are also used in other fields for the benefit of humanity. As mentioned in our previous study, algae can be used as an alternative in energy production.

They can also be used as fertilizers. Especially in Far Eastern cuisine, it is put into meals. In addition, their use is also possible to control the excessive growth of some species (https://gaiadergi.com/hayatimizi-alglere-borcluyuz/).

Algae with their enormous contribution to the atmosphere of the world, serves to enable us to reproduce the vitality and to create today's species for cosmetics industry and energy sector in many areas.

If one day you are asked the question that 'What is the most important species in the world?' we should not forget these species we owe our existence. 


\section{REFERENCES}

ARASAKI S. ve ARASAKI T. (1983). Low calor

ie, high nutrition vegetables from the sea to help look and feel better. Japan Publications, Tokyo, $196 \mathrm{p}$.

CHANDINI, S.K., GANESAN, P., SURESH, P.V. ve BHASKAR, N. (2008). Seaweeds as a source of nutritionally benefical compounds-a review. Journal of Food Science and Technology, 45(1), 1-13.

DURMAZ, Y., IŞIK, O., BANDARRRA, N.M., CIRİK, S., TURAN, G., \& GÖKPINAR, Ş. (2002). Porphyridium cruentum (Rhodophyceae) yağ asitleri kompozisyonuna kurutma yöntemlerinin etkisi. Ege Journal of Fisheries and Aquatic Sciences, 19(1-2), 189-195.

GÖKPINAR, Ş., GÖKSAN, T. ve DURMAZ, Y. (2001). PUFA kaynağı olarak mikroalgler, XI. Ulusal Su Ürünleri Sempozyumu, Hatay (pp. 779-785).

KASIMALA M., MEBRAHTU L., PASIENCE M., ASGEDOM G. (2015). Review on Biochemical Composition and Nutritional Aspects of Seaweeds, Caribbean Jounrnal of SciTech., 3, 789-797.

https://gaiadergi.com/hayatimizi-alglere-borcluyuz/

https://www.livestrong.com/article/427504-list-of-foods-that-contain-algae/

https://www.livestrong.com/article/458681-algae-as-a-food-source-for-humans/

http://www.businessinsider.com/algae-is-the-superfood-of-the-future-2014-6

https://www.webmd.com/vitamins-supplements 
TONGUC YAYINTAŞ \& IRKIN / Algae and Dietary Diets 